\title{
The examination of the effect of caffeine supplementation in professional soccer players
}

\author{
Karabağ S. ${ }^{\text {BCDE }}$, Taş Z. ${ }^{\text {ACDE }}$ \\ Faculty of Sports Science, Sakarya University of Applied Sciences, Sakarya, Turkey
}

Authors' Contribution: A - Study design; B - Data collection; C - Statistical analysis; D - Manuscript Preparation; E - Funds Collection.

\begin{abstract}
Purpose: In this study, the effects of caffeine supplementation in professional soccer players on the Hoff and sprint tests were examined.

Material: $\quad 11$ professional soccer players participated in this study in line with this purpose (Xage=20.636). The Hoff and sprint tests were applied 3 times at 1 week intervals. In each of these practices, caffeine added water was performed on the participants in the first week, and placebo was performed in the second week. In the third week, the participants were tested without any additional supplement. This practice lasted 3 weeks. Caffeine supplementation was given to each participant with the amount of $6 \mathrm{mg} / \mathrm{kg}$ in $200 \mathrm{ml}$ water 1 hour before the tests, and placebo supplementation in $200 \mathrm{ml}$ water was given 1 hour before the tests. The soccer players did the hoff test and sprint test respectively after 20 minutes of warming period.

Results: $\quad$ Following Wilcoxon signed-ranks analysis, it was found that caffeine supplementation and placebo applications significantly increased the hoff test averages $(p<0.05)$, while sprint test averages were reduced significantly in statistical terms $(p<0.05)$.

Conclusions: As a conclusion, we can state that caffeine application significantly increased the hoff test averages in comparison to placebo $(p<0.05)$, and that it caused sprint test averages to decrease significantly in statistical terms $(p<0.05)$.

Keywords: $\quad$ professional soccer player, caffeine, placebo, hoff test, sprint test.
\end{abstract}

\section{Introduction ${ }^{1}$}

The physical requirements of the soccer activity and the movements of the players in the competition have been the focus of many studies by sportsmen in recent times. These studies show that soccer has an intermittent nature that involves 3-5 second-long high-intensity movements such as jumps, turns, and sliding tackles $[1,2]$. Research findings have revealed that aerobic capacity, anaerobic power, strength, speed, flexibility, agility, balance, and coordination are the factors that lead to physical fitness in soccer [3, 4]. Achieving the goal in soccer depends on some factors. One of them is the technique of the soccer player, which is one of the factors that contribute to physical fitness. The basic form of performance in soccer depends on the broader use of capabilities [5].

For this reason, applications aiming to carry the physical condition of the players to advanced levels are planned, and the performance status of the players are examined with the tests performed from time to time. In some studies, the players are exposed to various evaluations in accordance with their positions on the pitch during the game, and some are examined totally regarding all their game positions on the pitch $[6,7]$.

With the features described above, efforts are made to increase the physical capacities of players and to further improve their performances through training. Different methods are applied to further improve the physical fitness level. Therefore, it is important that coaches continuously test the players' levels of performance and talent. While setting up a training program, it is also important to know

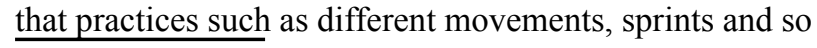
o Karabağ S., Taş Z., 2019

doi:10.15561/20755279.2019.0304 on that players are made to perform during training affect each other and are affected by one another. Therefore, movements that affect each other in a positive way can be taken into consideration while planning the practices [8].

It is also important to regulate the life habits as well as the training methods used to increase the performance levels of the players. These requirements can be considered sleep, rest and nutrition. Nutrition can be divided into pretraining and post-workout days. In order to increase their performance, athletes also use a number of nutritional support products. One of these products is caffeine. There are many reasons why caffeine is used by athletes. Caffeine causes stimulant effects, awake, improving physical performance, increasing performance, increasing attention, etc. are important reasons. Recently, many effects of caffeine on the central nervous system as well as on the heart and circulatory system, respiratory system and endocrine system have been investigated. Caffeine, especially on the nervous system with the stimulating effect of the athletes were found to be more alert and fit. In addition, the effect on the cardiovascular system is also known to accelerate the heart beat and expand the carcass (vasodilatation). In this way, it is predicted that more rapid blood flow will be provided to the cells and faster energy will be produced.

Therefore, caffeine has long been included in the excipients section of the list of prohibited substances, prepared by the World Doping Agency (WADA). But today it has been removed from the doping list.

The aim of this study was to investigate the effect of 6 $\mathrm{mg} / \mathrm{kg}$ caffeine loading on Hoff test and Sprint test.

Soccer 
Soccer, played by feet and based on team play, is the most popular sport in the world. It is based on the principle of scoring goal with a ball and two teams of 11 each. The history of soccer dates back to distant past. Many countries have claimed that they were the ones to play soccer for the first time. The widely accepted view, however, is that this sport was played for the first time in England and France. In the soccer of the Middle Ages and the soccer in England and France, in addition to the foot and the head, the ball could also be kicked by hand. At that time, especially in the UK, it attracted plenty of attention and almost became an epidemic. In 1314, the King of England, Edward II, banned soccer in his country because of the increased and unstoppable interest in soccer. In spite of King Edward II's prohibition, soccer continued to attract great interest and spread throughout the world. Soccer, which made great progress in the 17th century, spread throughout England in the 19th century [9].

\section{The concept of "Test" in soccer}

If the success of a training program in football or the targeted high-level performances are supported by tests or measurements, the programs prepared will be more successful. Thus, the results can be more easily obtained. The success of a test depends on the fact that the test actually measures the data to be obtained, so the tests to be used should be objective. The tests should have validity and reliability, should be repeatable, and should be objective enough to yield the same results independent of the tester. This is because the data obtained from the tests can be used to estimate future performance measurements, to determine weaknesses and strengths, and to show the emerging progress. Besides, the tests can be employed to measure the success of the existing training program, to determine the appropriate training groupings for athletes and to motivate athletes $[10,11]$.

Additionally tests can be used

- to evaluate the level of physical fitness,

- to prepare work schedule and calendar,

- to measure the effect of training programs and matches,

- to strengthen individual or team weaknesses,

- to motivate the players by giving objective information,

- to train soccer players,

- to make evaluation after rehabilitation and injury,

- to establish standards and player data bank for the future,

- to avoid overloads,

- to advise the coach or the manager,

- to improve soccer players,

- $\quad$ and to give confidence to the players regarding their capacity to perform better.

It should be kept in mind that some factors that affect test results should be minimized or even eliminated. Ambient temperature, humidity, noise level, and adequate sleep before testing are some of these factors. The mental state of the athlete, the treatment received by the athlete (if any), the time when the test is performed, the time of the last meal, and the test venue also affect test results. In addition, the experience and knowledge of the athlete and the tester about the test, the provision of sufficient staff to do the test, the accuracy of the measurement, and adequate warm-up are important factors to be considered [10].

As such, the tests to be applied in soccer are divided into two as laboratory and field tests. Likewise, coaches are divided into two groups among themselves as those who prefer laboratory or field tests. The reason for this is the type of work preferred by the coaches. Some of the coaches prepare training schedules according to the results of the measurements carried out in the laboratory, while some of them prepare those schedules according to the results of the measurements made in the field [12].

As popular laboratory tests, maximal aerobic power measurement (VO2max), lactic acid measurement and anaerobic power measurement tests are used in soccer. As laboratory tests are performed in a more controlled environment, the results are less affected by external factors in comparison to field tests. As a result, the measurement tools used in laboratory tests are considered valid and reliable. For this reason, laboratory tests yield more reliable and more detailed results than field tests [11]. Furthermore, individuals who practice outdoor sports in the field may not trust the results of the laboratory tests, and due to adaptation problems, they may fail to deliver satisfactory performance during the test [13].

Principles of application of technical tests in soccer

- Before applying the technical tests, the test elements should be determined and learned theoretically, and enough warm-up should be done in accordance with the test,

- The test should be tested for a specified period of time and for a specified number of movements in accordance with the purpose of the test,

- Necessary safety precautions should be taken at the place where the test is carried out, and principles of tools and equipment use should be obeyed,

- Technical tests should be carried out on the soccer field if possible,

- For the soccer players who will take technical tests, test should be administered under the same conditions as much as possible [14].

\section{The Hoff Test}

Hoff is a football-specific field test with ball movements, jumps, changing directions while running and sprints in it. The test starts with ball dribbling. Then, the athlete jumps over $30 \mathrm{~cm}$ high obstacles. Following this, the athlete runs around cones numbered 1, 2, 3, 4, 5 and 6 that are placed $25.5 \mathrm{~m}$. apart from each other respectively. Then, between the 7th and 8th cones, he runs backwards (Figure 1). Each round in the test is approximately $290 \mathrm{~m}$. The aim of the test is to reach the maximum distance in 8 minutes. A relationship of 0.96 was found between the distance traveled in the test and VO2 max [15]. Interval training includes repetitions of short and long-term, highintensity, intermittent low-intensity exercises or rests [16]. It is stated that the interval training performed at 
HRmax of $90-95 \%$ between 3 to 5 minutes has improved the endurance capacity [17].

The Sprint Test

Upon the start command, the athlete in start position in Figure 1 starts running from cone 3 . He runs straight at maximum speed to cone 1 and touches the cone with the right hand. He then runs at maximum speed to cone 2 and touches cone 2 with the left hand. Later, he runs at maximum speed to the right towards cone 3 and touches it with the right hand. As soon as the athlete reaches cone 3 , the chronometer is stopped. In this practice, the athlete performs a maximum of 3 repetitions with full rest. The best record achieved by the participant is recorded [18].

\section{Caffeine}

Caffeine is a substance that is used frequently with its areas of use increasing rapidly today. Caffeine makes the user physiologically and psychologically more sensitive by stimulating the central nervous system. It is also a substance that provides more effective use of coordination power, and with its effect on alertness, it increases attention by preventing fatigue and distraction. When this substance is combined with some painkillers and migraine drugs, it increases the response time and effective domains of drugs. Caffeine can also be used to reduce headache. Besides, it can be used for shortness of breath problems and postoperative problems of newborn children [19]. Caffeine used as a solution to these problems is beneficial,

$55 \mathrm{~m}$

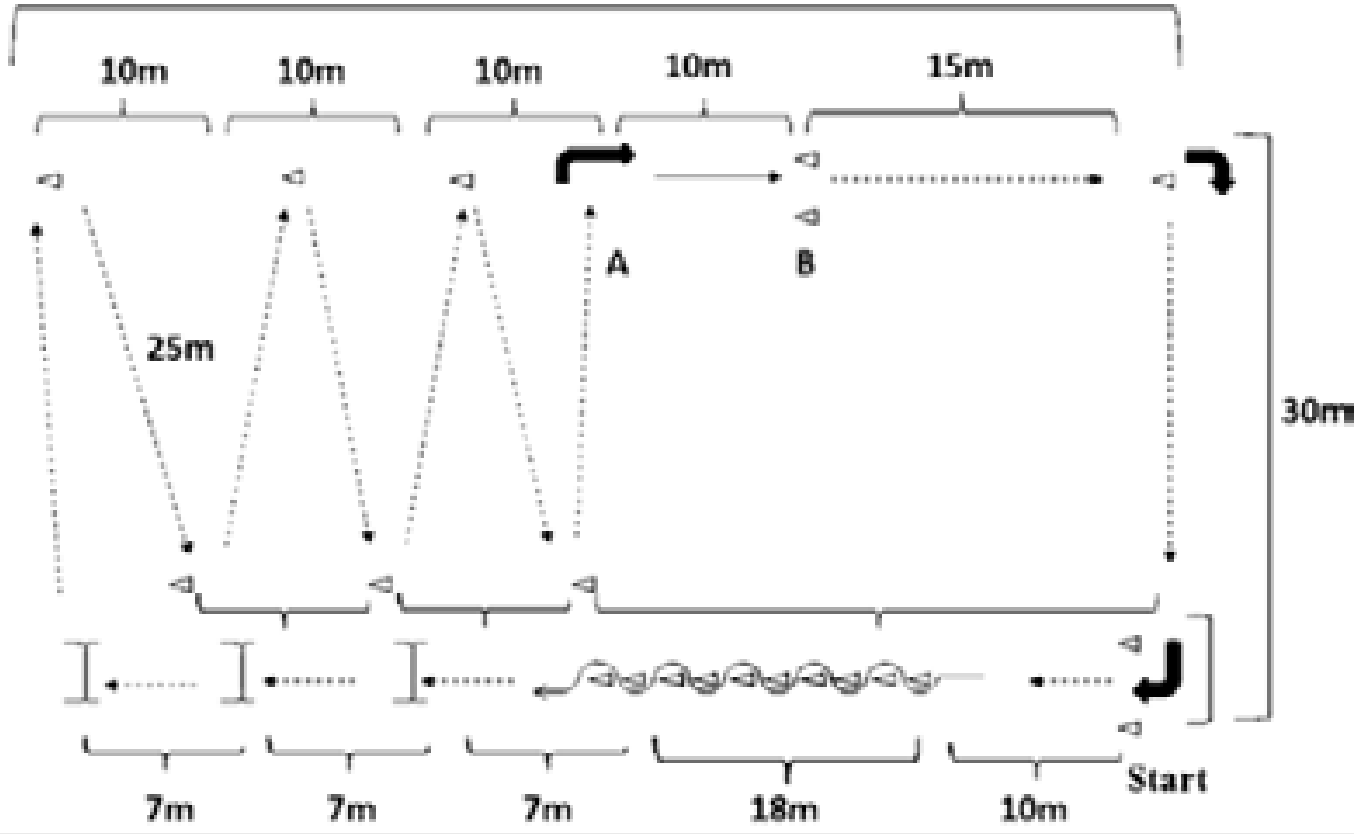

Figure 1. The Hoff Test $[14,15]$.

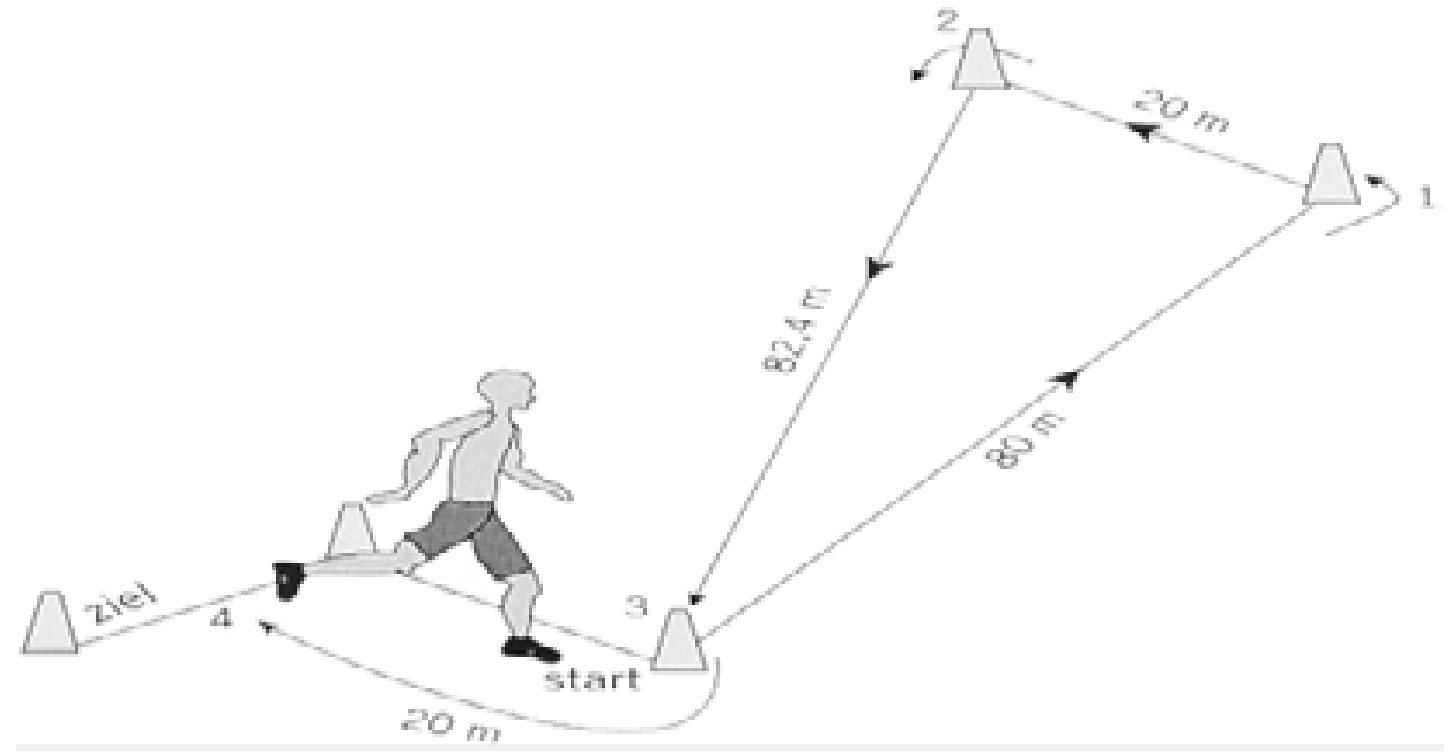

Figure 2. T-Test [14] 
but it produces some side effects in blood pressure in longterm use. In most studies, caffeine potentially produces ergogenic effects. These studies have been observed to provide effective benefits in submaximal, decreased performance in endurance exercise and increased fatigue [20]. In addition, caffeine contributes to the endurance performance by increasing the mobilization of fatty acids, thereby protecting glycogen storage. Caffeine also reduces the fatigue by facilitating the transport of calcium and by affecting muscle contraction and affects plasma potassium accumulation accompanying fatigue. The ergogenic effect of caffeine can be achieved with the consumption of $6.5-7 \mathrm{mg} / \mathrm{kg}$ before exercise. This positive effect of caffeine consumed before high-intensity exercises was not observed [21].

Physiological effects of caffeine

Caffeine is a substance that stimulates the functions of the central nervous system [22]. After oral intake, it is rapidly absorbed, and serum levels are maximized in 3060 minutes $[23,24]$. Caffeine moderately stimulates the functions of breathing by increasing the blood flow and ventilation of the lungs. Caffeine in 300-500 mg. doses increases the basal metabolic rate (BMR) by $10 \%$ and this effect lasts 4 hours. However, in terms of total basal metabolic rate (BMR), no difference was determined between those who take caffeine regularly and those who did not take any caffeine [25].

Effect mechanism of caffeine

Caffeine is a very strong mental stimulant. It may impair motor coordination [26]. Even in small doses of caffeine intake, rapid reaction and swift movement can be achieved [27]. The intensity of this effect can vary according to the amount of caffeine used, the physical structure of the individual, the type, intensity and duration of exercise, the habituation of the individual to methyl xanthine and the environmental factors during exercise [28]. High doses of caffeine intake in humans and rats increased blood pressure and augmented epinephrine release. This situation increased the risk of coronary heart disease in the adult population [29].

It has been determined in most of the studies done on the effect of caffeine on the performance of isolated muscles that it affected the performance by changing the mechanism of excitation-contraction and increasing the power formation in the muscle. Recent studies suggest that muscle types are important in evaluating the relation between caffeine and power formation in the muscle and fatigue [30]. Some researchers suggest that caffeine use only benefits athletes who have reached their performance level [31]. Caffeine can acutely and chronically increase growth hormone $(\mathrm{GH})$, thyroxine (T4) and thyroid stimulating hormone (TSH) levels. Studies show that caffeine consumption may play a protective role against benign or malignant thyroid neoplasia. In studies carried out in the past, it was observed that neoplasia did not increase in rats in whose drinking water caffeine was added for a long time. It was stated that caffeine alone decreased T4 levels and led to an increase in the levels of TSH. However, with 1500 ppm (approximately 140 $\mathrm{mg} / \mathrm{kg} /$ day; high dose) caffeine, thyroid follicular cell proliferation and liver hypertrophy were detected [32].

\section{Caffeine metabolism}

After oral intake of caffeine, $99 \%$ of it is absorbed from the gastrointestinal tract and reaches the highest concentration in plasma within 30-120 minutes. Due to its hydrophobic properties, it has the ability to easily pass through all biological membranes. Less than $5 \%$ of caffeine is excreted in the urine without metabolizing. After caffeine has reached the highest concentration in plasma, the concentration in the brain remains unchanged for at least one hour [33].

\section{Effect of caffeine on fat oxidation}

Does caffeine increase fat metabolism? Even if caffeine increases fat metabolism, fat oxidation is insignificant in some cases where caffeine is ergogenic such as strength training and short-term intensive activities. In addition, these studies have shown that caffeine did not reduce the rate of respiration change and did not increase plasma FFA levels. In 12 different studies in the laboratory of Van Someren, there was no reduction in the rate of respiration change after caffeine intake $[34,35]$.

In another study, caffeine intake increased arterial FFA levels. Important information has shown that caffeine increases adrenaline levels, and it was shown in another study [36] that the caffeine increased the sympathetic stimulation of legs. However, FFA mobilization occurs even in tetraplegics when there is no increase in catecholamine levels $[34,35]$. The author argues that the following scenario of fat metabolism occurs. Caffeine fires A1 receptors of adipocytes and this increases lipolysis (which can increase sympathetic activity and result in adrenergic receptor stimulation); increase in FFA levels results in increased hepatic intake of FFA, some of which are oxidized to triglycerides or esterified; excessive FFAs form ketone bodies that are released and discharged by various tissues, including skeletal muscle.

\section{Effect on muscle glycogen}

It has been shown that caffeine is useful in cases where the glycogen is limited in many exercise protocols (under 30 minutes of exercise) in which caffeine uses less glycogen. In addition, the literature on the effect of caffeine on muscle glycogen is limited. Early studies [37] showed that caffeine reduced glycogen use during longterm but not-up-to-the-level-of-exhaustion exercises. Other researchers [38] who found that it reduced net catabolism in the first 15 minutes of this exercise, were approved by Erickson et al. [39].

Although Jackman et al. [40] determined that caffeine increased the duration of endurance, they found no difference in muscle glycogen use during exercise at VO2max. Similarly, Chesley et al. [41] found no difference in glycogen after 3 or 15 minutes of exercise in $85 \%$ of $\mathrm{VO} 2$ max. Although caffeine and theophylline increased the endurance time in exercises which lasted 32 minutes, no difference was observed in either glycogen consumption or muscle glycogen in placebo trials. Greer et al. [42] found no difference in either glycogen consumption or muscle glycogen in placebo trials. Thus, 
even if glycogen was not used, no limiting factor was found in endurance time. Laurent et al. [43] reported that glycogen was not used because of the use of caffeine in exercises performed in $65 \%$ of VO2 max for 2 hours. In another study [44] in $70 \%$ of VO2 max of 10-minute and 60-minute exercises, no difference was detected in glycogen catabolism.

\section{The effect on lactate}

Some interesting issues regarding carbohydrate metabolism are increasingly being evaluated. According to the researchers $[41,44]$ caffeine intake significantly increases blood lactate levels. The dogma that this constitutes carbohydrate use is a paradoxical idea. Interestingly, this was probably more common than a decrease in RER associated with caffeine intake and an increase in FFA levels. In addition, the measurements of muscle acetylcholine and citrite $[42,44]$ generally do not support such a mechanism. Muscle lactate measurements in stable equilibrium exercises did not show any difference when theophylline and caffeine were consumed. In a study [42] it was clearly proved that caffeine increased the arterial lactate level during exercise.

Impact on energy status

Chesley et al., [41] found that caffeine increased the energy status due to less deposition of adenosine mono phosphate (AMP) and adenosine di phosphate (ADP) levels and lower phosphokreatine ( $\mathrm{PCr}$ ) degeneration. However, these changes were used only in the subgroup of participants in whom less muscle glycogen was used following caffeine intake. The importance of this finding is that the research was based on their glycogen information by dividing the participants into two groups and then examining their energy status in more detail. Marsh et al. [45] conducted a research as a pilot study using NMRS. The researchers studied 3 individuals who received theophylline and applied consecutive arm. Clearly, these findings have triggered greater research.

\section{Effect on catecholamines}

The endpoint of the glycogen use model is the increased sympathetic activity due to caffeine. Clearly, caffeine may increase the circulatory level of adrenaline [42, 44]. Only a few studies reported otherwise [46]. However, the increase is very moderate and controversial in terms of metabolic significance. When fatigue is delayed by electrically stimulating individuals' muscles [34] caffeine causes a normal increase in FFA levels of individuals in resting. With the increase of adrenaline levels, no difference occurred in AMP, ADP, ATP and $\mathrm{PCr}$ or measured lactate levels and muscle glycogen degeneration.

\section{Caffeine and exercise relationship}

In addition to training programs, some food supplements are being used in order to increase the athletes' performance. One of these supplements is caffeine.

Caffeine is used by athletes for many significant reasons, some of which are that caffeine has a stimulatory effect, keeps athletes awake, improves performance by eliminating physical exhaustion, increases attention, and so on. Recently, the effects of this substance on the heart and circulatory system, respiratory system and endocrine system, as well as on the central nervous system, have been investigated. The stimulating effect of caffeine especially on the nervous system has been determined to keep athletes more alert and fitter. Moreover, with its effects on the cardiovascular system, it is known to accelerate heartbeats and expand the blood vessels (vasodilatation). In this way, it has been suggested that the cells will be provided with faster blood flow resulting in faster energy generation.

Therefore, caffeine was long included in the stimulants section of the prohibited substances list prepared by the World Doping Agency (WADA). However, it has been removed from the doping list today [47].

The purpose of this study is to investigate the effects of daily caffeine supplementation of $6 \mathrm{mg} / \mathrm{kg}$ to professional soccer players on Hoff test and sprint test.

Foskett et al. [48] examined a soccer player who was administered a moderate dose of caffeine supplement (6 $\mathrm{mg} / \mathrm{kg}$ ) in terms of his aesthetics of passing the ball and his ability to control the ball. At the end of the research, it was observed that the player's ability to pass the ball accurately and the ability to control the ball improved. This shows the positive effect of caffeine in performing fine motor skills.

\section{The effect on endurance in long-term exercises}

Most investigators examined fatigue occurring in endurance exercises between 30 and 60 minutes. It was found that caffeine had an ergogenic effect on this situation [42] but only a few studies determined the opposite [49]. Even in 30-minute exercises in which exhaustion occurred, the effect of caffeine was observed. Under this condition, the muscle glycogen was probably depleted. In another study [50] more than $50 \%$ of glycogen remained in fatigue, which revealed that the breakdown of glycogen in such conditions did not limit the study.

The effect on speed and power in long-term exercises

Studies on the effect of caffeine on performance or speed in endurance exercises are rarely conducted. Some studies determined that caffeine often increases performance in activities such as stepping up and repetitive jumping as well as sprint test and cycling [51, 52, 53, 54]. These studies were often applied to small groups and in protocols that are not accepted today. Berglund and Hemmingsson [55] found that caffeine led to an increase in high-speed movements of cross-country skiers participating in the competitions. This study is controversial because the researcher compared his knowledge in a complex way. However, each test is difficult, and skiing is an ungrateful sport because it is almost impossible to predict when and how long it will snow. Researchers studied elite skiers in both high and low altitudes from 20 to $23 \mathrm{~km}$. Marking was done both at the halfway and at the finish line, and it was revealed that caffeine absorption resulted in faster finishing time. The total time was approximately 55 to 67 minutes, and the athletes who were administered caffeine were found to be 33 to 101 seconds faster at both high and low altitudes. Similarly, the athletes who were 
given caffeine at finishing time were found to be 59 to 152 seconds faster at both high and low altitudes (there was a statistically significant difference between the lowaltitude exercises and the finishing time $\mathrm{p}<0.10$ ).

The effect on power in short-term high intensity exercises

Wiles et al. [56] gave the participants $1500 \mathrm{~m}$ running test and observed that caffeine intake caused a significant increase in running speed by 4.2 seconds. However, it should be known that this study was done on elite athletes. No correlation was found between the increase in caffeine intake and running speed or caffeine intake habits. Colomp et al. [57] studied $100 \mathrm{~m}$ free style swimmers. While caffeine intake led to no increase in the athletes without training, it created a significant increase of about 1 second in average time in the athletes with high training levels.

When short-term activities were examined, the results seemed to be more complicated as the exercise was short and intense, and the measurements were minimal and thus hard to make. Anselme et al. [58] found that caffeine increased sprint at maximal power by 6 seconds, but that it caused no increase in 30-second Wingate test.

\section{Prescription for optimal Use}

Does the method of caffeine intake make any difference in the effect of caffeine? No clear answer is available for this question. That's why, a comparison that has never been made before should be made. Caffeine and other methylxanthines can be taken through intramuscular injection, venous infusion, suppository or orally. Most researchers administer caffeine orally either purely, through a capsule or in water solution. In most studies, only one dose was administered orally, but in a few studies doses were repeated. It was not determined how caffeine should be taken and what dose should be administered when [59].

\section{Timing}

Most researchers administered caffeine one hour before the exercise and after the exercise. This protocol was chosen because caffeine is absorbed quickly and plasma concentration reaches the maximum level approximately in 1 hour. No information about the plasma concentration of caffeine and differences among participants regarding it is available in most studies. Caffeine is slowly catabolized (halving time is 4-6 hours), and individuals maintain circulation concentration at this level for 3 to 4 hours. It was claimed that since lipolysis due to caffeine produces free fatty acids at the highest level, waiting for three hours is the optimal choice [60]. However, this hypothesis has not been tested, and the ergogenic role of these lypolisis is very doubtful.

\section{Dosage}

Interestingly, some researchers administered caffeine in a certain dose rather than basing the dosage on the individual's body mass. This may result in variations in the responses. In a few studies, caffeine was administered based on body mass without fats. However, caffeine dissolves both in water and fat, and possibly body fat is an important factor for caffeine distribution. As mentioned above, most researchers did not report the plasma caffeine concentration of participants, which renders the understanding of some studies as inconsistent in the literature. In the laboratory of Graham and McLean, the plasma caffeine concentration was routinely measured. The caffeine administered on the basis of body mass was shown to result in a very intensive plasma caffeine concentration in both women and men [61]. In general, the average caffeine doses of women with less body weight were approximately $20 \%$ higher than those of men. In addition, most of these studies did not examine gender differences.

\section{Placebo}

"Placebo", a Latin word, means "I will please." It implies a subjective positive effect of something taken for the purpose of the drug or remedy. The opposite is the concept "nocebo", meaning 'I will hurt', and it refers to a negative subjective experience [62].

Brody [63] suggested that the placebo effect has four basic definitions. Among these, we mentioned the definition "specific effects of a treatment as well as the resulting non-specific effect" in the" Introduction" section, which has lost its significance in recent years. Other definitions are as follows and each definition has close meanings:

a) Therapeutic effect produced by an ineffective drug in terms of medical biology (biomedically)

b) The therapeutic effect or side effect of a drug, which cannot be explained by its pharmacological properties

c) The effect that is common to all treatments ... Brody (1982) described placebo under a definition covering all these definitions "as an attempt to accelerate the medical treatment or medical treatment method which is benefited from its symbolic effect and is believed not to show a specific activity for a treatment situation by the physician" and suggested the concept of "symbolic effect ", which we will discuss in the "conclusion" section.

Forrester [64] a sociologist, argued that the placebo effect is never limited to this definition, although placebo has been widely used in health sciences "as a drug to test the hypotheses of experimental scientific medicine." Indeed, Forrester has a point in this criticism. In fact, placebo control groups were used even in some animal experiments without the need to define the placebo effect $[65,66]$. According to Forrester, the placebo effect should include the mood of the clinic or the practice of the physician, the physician's manner of reasoning when faced with problems, the efforts to soothe the patient, and the trust and understanding created by the physician, especially if the physician and the patient have a long history. To Forrester, the placebo effect is also related to power relations. The role of the physician profession and the physician's ability to make the patient feel better also play a role in the placebo effect. Referring to Spiro [67] who has done many studies on the placebo effect, Forrester argues that not only the physician-patient relationship but also the recent high-tech spell should be considered in the placebo effect. Forrester states that this is related to "fraud", "cheating" and "lie" because the 
Table 1. Summary of The Study on The Effect of Caffeine on Exercise Performance

\begin{tabular}{|c|c|c|c|c|}
\hline Resource & Participants & Caffeine dose & Protocol & Results \\
\hline Ivy et al. & $\begin{array}{l}\text { 7M, 2F; Trained } \\
\text { Cyclists }\end{array}$ & $\begin{array}{l}250+250 \mathrm{mg} \\
(\mathrm{M}: 6.9, \mathrm{~F}: 8.8)\end{array}$ & $\begin{array}{l}\text { Max on bicycle for } 2 \\
\text { hours Load }\end{array}$ & $\begin{array}{l}\text { Caffeine: } 7.4 \% \text { more } \\
\text { work; } 31 \% \text { more fat } \\
\text { burn; the same running } \\
\text { time }\end{array}$ \\
\hline Cohen et al. & $\begin{array}{l}5 \mathrm{M}, 2 \mathrm{~F} ; \text { Trained } \\
\text { runners }\end{array}$ & $\begin{array}{l}a: 0, b: 0, c: 2.1 \\
d: 3.2, e: 4.5\end{array}$ & $\begin{array}{l}21 \mathrm{~km} \text { run in hot and } \\
\text { damp circumstance }\end{array}$ & $\begin{array}{l}\text { No difference in running } \\
\text { time }\end{array}$ \\
\hline Berglund\&Hemmingson & $\begin{array}{l}\text { 8-10M: 4-5F } \\
\text { Trained skier }\end{array}$ & $6 \mathrm{mg} / \mathrm{kg}$ & $\begin{array}{l}\mathrm{n}=13 \text { high altitude } 23 \\
\mathrm{~km} \mathrm{n}=14 \text { sea level } 20 \\
\mathrm{~km} \text { competition }\end{array}$ & $\begin{array}{l}\text { Ones with caffeine } \\
\text { intake were faster in } \\
\text { the } 1 \text { st and } 2 \text { nd laps } \\
(p<0.10)\end{array}$ \\
\hline Kovacs et al. & $\begin{array}{l}\text { 15M; Trained } \\
\text { Cyclist }\end{array}$ & $\begin{array}{l}a: 0, b: 0, c: 2.1 \\
d: 3.2, e: 4.5\end{array}$ & $\begin{array}{l}\text { Stimulant for about an } \\
\text { hour }\end{array}$ & $\begin{array}{l}\text { Time (min): a:62.5, } \\
\text { b: } 61.5, c: 60.4, d: 58.9, \\
\text { e:58.9 }\end{array}$ \\
\hline Macintosh\&Wright & $\begin{array}{l}\text { 7M, 4F; Trained } \\
\text { Swimmers }\end{array}$ & $6 \mathrm{mg} / \mathrm{kg}$ & 1500 m swimming & $\begin{array}{l}\text { With caffeine: } 500 \text { m:7 } \\
\text { sec, } 1000 \text { m: } 8 \mathrm{sec}, 1500 \\
\text { m: } 23 \text { sec faster }\end{array}$ \\
\hline Bruse et al. & 8M Rower & $a: 0, b: 6, c: 9$ & $2000 \mathrm{~m}$ rowing & $\begin{array}{l}\text { Time (sec): a:416, } \\
\text { b:411*, c:412* }\end{array}$ \\
\hline Wiles et al. & $\begin{array}{l}\text { 18M; 10M; } \\
\text { Trained runners }\end{array}$ & $2-2.5 \mathrm{mg} / \mathrm{kg}$ & $\begin{array}{l}1500 \text { m running a: ran } \\
\text { controlled b: } 1100 \\
\text { m controlled, then } \\
\text { finished pulling up } \\
\text { knees. }\end{array}$ & $\begin{array}{l}\text { a } / \mathrm{sec}): \mathrm{pl}: 290 ; \\
\text { caffeine:286.* }, \mathrm{b} \text { final } \\
400(\mathrm{~km} / \mathrm{h}): \mathrm{pl}: 22.9, \\
\text { caffeine: } 23.5\end{array}$ \\
\hline Collomp et al. & $3 \mathrm{M}, 3 \mathrm{~F}$ active & $5 \mathrm{mg} / \mathrm{kg}$ & Wingate test & $\begin{array}{l}\text { No difference in } \\
\text { exhaustion rate or } \\
\text { average and maximum } \\
\text { power }\end{array}$ \\
\hline Greer et al. & 9M, active & $6 \mathrm{mg} / \mathrm{kg}$ & $\begin{array}{l}4 \text { Wingate test in } \\
\text { 4-minute intervals }\end{array}$ & $\begin{array}{l}\text { No difference in } \\
\text { exhaustion rate or } \\
\text { average and maximum } \\
\text { power }\end{array}$ \\
\hline Anselme et al. & $10 \mathrm{M}, 4 \mathrm{~F}$ active & $250 \mathrm{mg}$ & $\begin{array}{l}6 \text { sec sprint gradual } \\
\text { load cycling ( } 5 \text {-minute } \\
\text { rest) }\end{array}$ & $\begin{array}{l}\text { Caffeine: max. Power } \\
964 \text { vs } 940 W^{*}\end{array}$ \\
\hline
\end{tabular}

patient must be unaware of what has been done to him to create the placebo effect, and raises the question "is there any justification for any form of medical treatment that obliges the patient to be deceived?"

\section{Material and methods}

Participants

11 soccer players playing in professional leagues participated in the study. Participants were involved in the study when they were in the passive period before the camp preparation period, without engaging in any sporting activity. The mean age of the football players was $20.67 \pm$ 0.72 years, the mean height was $179.13 \pm 7.38 \mathrm{~cm}$ and the body weight average was $74.27 \pm 4.68 \mathrm{~kg}$.
None of the participants had experienced a neurological disease or vestibular-visual disorder in the previous year and none had a severe lower extremity disability within the last 6 months. Before the study, each participant was given detailed information about the risks and discomforts related to the study, and each was made to read and sign the volunteer consent form.

\section{Caffeine Intake}

In the study, the Hoff and sprint tests were applied 3 times with a one-week interval. In each of these practices, caffeine added water was applied to the participants in the first week, and the placebo was administered in the second week. In the third week, the participants were tested without any additional supplement. This practice lasted 
3 weeks. Caffeine supplementation was given to each participant at an amount of $6 \mathrm{mg} / \mathrm{kg}$ in $200 \mathrm{ml}$ of water 1 hour before the tests, while the placebo supplementation was administered as $200 \mathrm{ml}$ of water 1 hour before the tests.

\section{Research Design}

The Hoff and sprint tests to be applied in the study were applied 3 times at 1 week intervals. In each of these practices, caffeine added water was performed on the participants in the first week, and placebo was performed in the second week. In the third week, the participants were tested without any additional supplement. This practice lasted 3 weeks. Caffeine supplementation was given to each participant with the amount of $6 \mathrm{mg} / \mathrm{kg}$ in $200 \mathrm{ml}$ water 1 hour before the tests, and the placebo supplementation in $200 \mathrm{ml}$ water was administered 1 hour before the tests.

Test Protocol

The technical test protocol was applied to the subjects as follows.

Warm-up phase: Test-specific warm-up program for 20 minutes.

Test Phase: The Hoff Test and Sprint Test for Soccer Players were performed.

Completion stage: consists of 10-minute jogging and stretching.

Statistical Analysis

SPSS for Windows 21.0 package program was used for the statistical evaluation of all measured data. Mean and standard deviations of the data obtained from the participants were calculated. In order to determine the effect of each experiment, Wilcoxon signed rank analysis test was applied.

\section{Results}

In this part of the study, the findings of the analyses using the data of the participants were converted into tables and interpreted.

According to Table 1, the average age of participants was 20,636 with a standard deviation of 0,8090 ; the weight average was $74,273 \mathrm{~kg}$ with a standard deviation of 4,7768 ; the average height was $1.7936 \mathrm{~m}$ with a standard deviation of 0.07580 .

When Table 2 is examined, Wilcoxon signed rank analysis of the Hoff test scores shows a statistically significant difference in favor of the placebo group ( $p$ $<0.05)$. According to this result, it can be concluded that placebo application increased the endurance of the group.

When Table 3 is examined, Wilcoxon signed rank analysis of the Hoff test scores shows a statistically significant difference in favor of the caffeine group ( $p$ $<0.05)$. According to this result, it can be concluded that caffeine application increased the endurance of the group.

When Table 4 is examined, Wilcoxon signed rank analysis of the Hoff test scores shows a statistically significant difference in favor of the caffeine group ( $p$ $<0.05)$. According to this result, it can be concluded that caffeine application increased the endurance level of the group more than the placebo application.

When Table 5 is examined, Wilcoxon signed rank analysis of the Sprint test scores shows a statistically significant difference against the placebo group $(\mathrm{p}<0.05)$. According to this result, it can be concluded that placebo application increased the dexterity level of the group.

When Table 6 is examined, Wilcoxon signed rank analysis of the Sprint test scores shows a statistically significant difference against the caffeine group $(\mathrm{p}<0.05)$.

Table 2: Descriptive Statistics

\begin{tabular}{|c|c|c|c|c|}
\hline Descriptives & & Age & Weight & Height \\
\hline \multirow{2}{*}{$n$} & Valid Data & 11 & 11 & 11 \\
\hline & Missing Data & 0 & 0 & 0 \\
\hline Average & & 20.636 & 74.273 & 1.7936 \\
\hline Median & & 21.000 & 76,000 & 1.7800 \\
\hline Mod & & 21,0 & $69.0 a$ & $1.72 \mathrm{a}$ \\
\hline Std. Deviation & & .8090 & 4.7768 & .07580 \\
\hline Minimum & & 19.0 & 66.0 & 1.69 \\
\hline Maximum & & 22.0 & 80.0 & 1.91 \\
\hline
\end{tabular}

Table 3: Wilcoxon Signed Rank Analysis Results of Placebo Application (The Hoff Test)

\begin{tabular}{|c|c|c|c|c|c|c|}
\hline Mathematical Expression & Ranks & $\mathbf{n}$ & Mean Rank & $\begin{array}{l}\text { Total } \\
\text { Ranks }\end{array}$ & $\mathbf{Z}$ & $\mathbf{p}$ \\
\hline \multirow{4}{*}{ The Hoff Test Placebo - The Hoff Test Control } & Negative ranks & $1^{\mathrm{a}}$ & 3.00 & 3.00 & \multirow{4}{*}{-2.669} & \multirow{4}{*}{.008} \\
\hline & Positive ranks & $10^{\mathrm{b}}$ & 6.30 & 63.00 & & \\
\hline & Equal & $0^{c}$ & & & & \\
\hline & Total & 11 & & & & \\
\hline \multicolumn{7}{|l|}{ a. The Hoff Test Placebo < The Hoff Test Control } \\
\hline \multicolumn{7}{|l|}{ b. The Hoff Test Placebo > The Hoff Test Control } \\
\hline c. The Hoff Test Placebo $=$ The Hoff Test Contrc & & & & & & \\
\hline
\end{tabular}


Table 4: Wilcoxon Signed Rank Analysis Results of Caffeine Application (The Hoff Test)

\begin{tabular}{|c|c|c|c|c|c|c|}
\hline Mathematical Expression & Ranks & $\mathbf{n}$ & Mean Rank & Total Ranks & $\mathbf{Z}$ & $\mathbf{p}$ \\
\hline \multirow{4}{*}{ The Hoff Test Caffeine - The Hoff Test Control } & Negative ranks & $0^{\mathrm{a}}$ & .00 & 0.00 & & \\
\hline & Positive ranks & $11^{\mathrm{b}}$ & 6.00 & 66.00 & -2.934 & .003 \\
\hline & Equal & $0^{c}$ & & & & \\
\hline & Total & 11 & & & & \\
\hline \multicolumn{7}{|c|}{ a. The Hoff Test Caffeine < The Hoff Test Control } \\
\hline \multicolumn{7}{|l|}{ b. The Hoff Test Caffeine > The Hoff Test Control } \\
\hline \multicolumn{7}{|l|}{ c.The Hoff Test Caffeine = The Hoff Test Control } \\
\hline
\end{tabular}

Table 5: Wilcoxon Signed Rank Analysis Results of Caffeine and Placebo Application (The Hoff Test)

\begin{tabular}{|c|c|c|c|c|c|}
\hline Mathematical Expression & Ranks & n Mean Rank & Total Ranks & $\mathbf{Z}$ & $\mathbf{p}$ \\
\hline \multirow{4}{*}{ The Hoff Test Caffeine - The Hoff Test Placebo } & Negative ranks & $\mathrm{s}^{\mathrm{a}} \quad .00$ & 0.00 & & \\
\hline & Positive ranks & $11^{\mathrm{b}} 6.00$ & 66.00 & -2.936 & .003 \\
\hline & Equal & $0^{c}$ & & & \\
\hline & Total & 11 & & & \\
\hline \multicolumn{6}{|c|}{ a. The Hoff Test Caffeine < The Hoff Test Placebo } \\
\hline \multicolumn{6}{|l|}{ b. The Hoff Test Caffeine > The Hoff Test Placebo } \\
\hline \multicolumn{6}{|l|}{ c. The Hoff Test Caffeine $=$ The Hoff Test Placebo } \\
\hline
\end{tabular}

Table 6: Wilcoxon Signed Rank Analysis Results of Placebo Application (Sprint Test)

\begin{tabular}{lllll}
\hline Mathematical Expression & Ranks & $\mathbf{n}$ Mean Rank & Total Ranks Z & $\mathbf{p}$ \\
\hline & Negative ranks $11^{\text {a } 6.00}$ & 66.00 & -2.936 & .003 \\
Sprint Test Placebo - Sprint Test Control & Positive ranks & $0^{\text {b }} .00$ & .00 & \\
& Equal & $0^{\text {c }}$ & & \\
& Total & 11 & & \\
a. Sprint Test Placebo < Sprint Test Control & & & & \\
b. Sprint Test Placebo $>$ Sprint Test Control & & & & \\
c. Sprint Test Placebo $=$ Sprint Test Control & & & & \\
\hline
\end{tabular}

Table 7: Wilcoxon Signed Rank Analysis Results of Caffeine Application (Sprint Test)

\begin{tabular}{|c|c|c|c|c|c|c|}
\hline Mathematical Expression & Ranks & $\mathbf{n}$ & Mean Rank & $\begin{array}{l}\text { Total } \\
\text { Ranks }\end{array}$ & Z & $\mathbf{p}$ \\
\hline \multirow{4}{*}{ Sprint Test Caffeine - Sprint Test Control } & Negative ranks & & 6.00 & 66.00 & & \\
\hline & Positive ranks & $0^{\mathrm{b}}$ & .00 & .00 & -2.934 & .003 \\
\hline & Equal & $0^{c}$ & & & & \\
\hline & Total & 11 & & & & \\
\hline \multicolumn{7}{|l|}{ a. Sprint Test Caffeine $<$ Sprint Test Control } \\
\hline \multicolumn{7}{|l|}{ b. Sprint Test Caffeine $>$ Sprint Test Control } \\
\hline c. Sprint Test Caffeine $=$ Sprint Test Control & & & & & & \\
\hline
\end{tabular}

Table 8: Wilcoxon Signed Rank Analysis Results of Caffeine and Placebo Application (Sprint Test)

\begin{tabular}{|c|c|c|c|c|c|c|}
\hline Mathematical Expression & Ranks & $\mathbf{n}$ & Mean Rank & $\begin{array}{l}\text { Total } \\
\text { Ranks }\end{array}$ & $\mathbf{z}$ & $\mathbf{p}$ \\
\hline \multirow{4}{*}{ Sprint Test Caffeine - Sprint Test Placebo } & Negative ranks & & 6.00 & 66.00 & & \\
\hline & Positive ranks & $0^{\mathrm{b}}$ & .00 & .00 & -2.934 & .003 \\
\hline & Equal & $0^{c}$ & & & & \\
\hline & Total & 11 & & & & \\
\hline \multicolumn{7}{|l|}{ a. Sprint Test Caffeine < Sprint Test Placebo } \\
\hline \multicolumn{7}{|l|}{ b. Sprint Test Caffeine $>$ Sprint Test Placebo } \\
\hline c. Sprint Test Caffeine $=$ Sprint Test Placebo & & & & & & \\
\hline
\end{tabular}


According to this result, it can be concluded that caffeine application increased the dexterity level of the group.

When Table 7 is examined, Wilcoxon signed rank analysis of the Sprint test scores shows a statistically significant difference against the caffeine group $(p<0.05)$. According to this result, it can be concluded that caffeine application increased the dexterity level of the group more than the placebo application.

\section{Discussion}

There are many studies in the literature in which the effects of caffeine on sports performance were investigated. These studies have revealed that beverages containing caffeine improve reaction time and increase aerobic and anaerobic endurance. They are also reported to reduce drivers' insomnia and to improve marksmanship, surveillance and psychomotor fitness in soldiers [68, 69, 70, 71]. Furthermore, there are studies on the ergogenic effect of caffeine intake before moderate intensity exercise $[72,73]$. The accessed literature shows that performance benefits of moderate caffeine intake can be observed in sports that require endurance and involve high intensity activities [70]. As a result, caffeine supplementation can be said to increase sports performance.

In this study, caffeine supplementation of $6 \mathrm{mg} / \mathrm{kg}$ was administered to 11 professional soccer players involved in no sports activities prior to the preparation period. It was determined that caffeine supplementation significantly increased the Hoff test averages of the participants and decreased the sprint test times, thus positively affecting the strength and speed performance. Placebo supplementation, on the other hand, showed less effect compared to caffeine supplementation, but compared to no-supplementation cases, better results were achieved in the tests.

Astorino and others examined the effect of 5 and $2 \mathrm{mg} /$ $\mathrm{kg}$ of caffeine intake on muscular strength and muscular endurance performance in an isokinetic ergometer. They reported that $2 \mathrm{mg} / \mathrm{kg}$ of caffeine intake did not affect muscular performance or muscle pain perception, but 5 $\mathrm{mg} / \mathrm{kg}$ of caffeine intake improved muscular performance and decreased muscle pain [74].

In a similar study, Foskett et al. (2009) analyzed the effect of caffeine supplementation $(6 \mathrm{mg} / \mathrm{kg})$ on the soccer players' skills to pass the ball and their ball control techniques. This study revealed that the shot on target rate of players increased and their ball control techniques improved, which shows the positive effect of caffeine on the performance of fine motor skills. In another study Lara et.al., (2014) in which female soccer players were administered caffeine and placebo ( $3 \mathrm{mg} / \mathrm{kg}$ ) supplementation in two separate periods, a significant difference was observed in favour of caffeine supplementation in terms of jumping scores and sprint speeds compared to placebo. In a simulated competition, higher scores were achieved through caffeine supplementation than through placebo in terms of running distance, the number of sprints and the distance taken at a speed higher than $18 \mathrm{~km} / \mathrm{h}$ [69]. In yet another study,
Wiles et. al. (1985) administered a $1500 \mathrm{~m}$ running test to the participants and identified that caffeine intake led to a significant increase in running speed [56].

Ivy et. al. (1979) showed that caffeine intake following 2-hour bicycle exercise caused an increase in the total power output of the participants [37]. Hogervorst and others (2008) did a study on caffeine intake of cyclists. This study suggested that there were significant improvements in participants' exercise duration, exercise intensity, and cognitive function tests [72].

Hewlett and Smith (2007) point to the significant effect of caffeine supplementation on the soccer players' test duration by referring to its stimulating effect on the nervous system, which results in sportspeople being fitter and more alert [75].

Haskell et. al. carried out a study involving a group of young male participants. The study revealed that caffeine supplementation improved reaction time and increased concentration and the number of correct answers to the questions asked [76].

Kennedy and Scholey (2004) conducted a study on the effects of beverages containing caffeine and glucose on the fatigue resulting from long-lasting activities. It was observed that the combined consumption of caffeine and glucose caused improvements in performance and personal fatigue [76]. In their study, Holston and Jeukendrup (2008) found that caffeine-glucose solution increased performance by $9 \%$ compared to placebo and by $4.6 \%$ in comparison to glucose [68].

In contrast, Collomp et. al. (1990) claimed that short term or long term caffeine consumption did not reveal a significant level of difference when compared to placebo [57]. In addition, there are also studies Hindmarch et. al., (1998); Herz, (1999) which argue that caffeine does not have a significant effect $[77,78]$.

It can be stated that differences in various studies may be related to method selection, training level, participant selection and the amount of caffeine supplementation.

\section{Conclusion}

In this study, caffeine supplementation of $6 \mathrm{mg} / \mathrm{kg}$ was administered to 11 professional soccer players involved in no sports activities prior to the preparation period. It was determined that caffeine supplementation significantly increased the Hoff test averages of the participants and decreased the sprint test times, thus positively affecting the strength and speed performance. Likewise, though the placebo supplementation showed less effect compared to caffeine supplementation, better results were achieved in the tests compared to no-supplementation cases.

The studies referred to in the discussion part of our study showed that caffeine supplementation has a positive effect concerning Hoff and Sprint tests. Evaluation of the effects of caffeine supplementation on branch-specific performances of players in different branches may provide new insights for research. Obviously, more research should be carried out to determine the positive or negative effects of caffeine supplementation on speed, strength and endurance performance. Another important result to be 
considered is the placebo effect. The positive effects of this symbolic effect have been revealed in many studies conducted in medicine and psychiatry so far. Therefore, this positive role of the placebo effect, which we think is not sufficiently examined, should be reconsidered in relation to sports sciences and better understood.

\section{Acknowledgements}

The authors would like to thank the study participant for their dedication and effort throughout the study.

\section{Conflict of interest}

The authors declare no conflict of interest.

\section{References}

1. Castagna C, Impellizzeri FM, Chamari K, Carlomagno D, Rampinini E. Aerobic Fitness And Yo-Yo Contionus And Intermittent Tests Performances İn Soccer Players: A correlation study. Journal of Strength and Conditioning Research, 2006; 20: 320-325. https://doi.org/10.1519/R-18065.1

2. Krustrup P, Mohr M, Nybo L, Majgaard JJ, Nielsen JJ, Bangsbo J. The Yo-Yo İr2 Test: Physiological Response, Reliability, And Application To Elite Soccer. Medicine and Science in Sports and Exercise, 2006; 38: 1666-1673. https://doi.org/10.1249/01.mss.0000227538.20799.08

3. İşleğen Ç. Physical And Physiological Profiles Of Regional Professional Football Teams Playing İn Different Leagues. Turkish Journal Of Sports Medicine, 1987; 22: 83-89.

4. Açıkada C, Hazır T, Așçı A, Turnagöl H. Physical And Physiological Profiles Of A Second League Division Soccer Team During Preparation Period. Journal of Football Science and Technology, 1999; 1: 14-20.

5. Lees A, Nolan L. The Biomechanics Of Soccer: A Review. Journal Of Sports Sciences. 1998; 16: 211-234. https://doi.org/10.1080/026404198366740

6. Tamer K, Cicioğlu İ, Yüce A, Çimen O. Comparison Of Some Physical And Physiological Characteristics of Professional Football Players Fighting in Three Different Leagues. Journal of Football Science and Technology; 1996; 2: 22-25.

7. Temuçin S, Avluk AI, Binokay S, Koçyigit F, Öztürk F. The Effect Of Age, Body Fat Ratio And Some Motoric Characteristics Of The Positions They Play On Football Players. 22nd National Physiology Congress Abstract Book. Bursa, 1996. P. 100.

8. Rauf Onur EK, Temoçin S, Tekin T.A, Yıldız Y. Investigation of the Effects of Some Motorsal Exercises on Football Players. ADÜ Medical Faculty Journal, 2007; 8(1):19-22.

9. Arslan FN. The Nutrition Knowledge and Habits of Professional Football Players, [Master Thesis], Gazi University, Ankara. 1995.

10.Mackenzie B. 101 Performance Evaluation Tests. London: Electric Word plc; 2005.

11.Svensson M. Drust B. Testing Soccer Players. Journal of Sports Sciences, 2005; 23(6): 601-618. https://doi.org/10.1080/02640410400021294

12.Jensen P. Lactate Threshold Training. Human Kinetics, Chapter II; 2001.

13.Bangboso J, IAIA, JFM ve Krustrup, P. The YoYo Intermittent Recovery Test: A Useful Tool For Evaluation Of Physical Performance İn Intermittent Sports. Sports Medicine, 2008; 38 (1): 37-51. https://doi.org/10.2165/00007256-200838010-00004

14.Özkara A. Tests in Football, 1st ed, Ankara: Ilksan Printing; 2004.

15.Hoff J, Wisloff U, Engen LC, Kemd O, Helgerud J. Soccer Specific Aerobic Endurance Training. Br. J. Sports Med, 2002;36:218-221. https://doi.org/10.1136/bjsm.36.3.218

16.Billat L.V. Interval Training for Performance: A Scientific and Empirical Practice. Sports Med, 2001; 31(1): 13-31. https://doi.org/10.2165/00007256-200131010-00002.

17.Hoff J, Helgerud J. Endurance And Strength Training For Soccer Players. Sports Med, 2004; 34 (3): 165-180. https://doi.org/10.2165/00007256-200434030-00003

18.Kizilet A, Atılan O, Erdemir I. The Effect of The Different Strength Training on Quickness and Jumping Abilities of Basketball Layers Between 12 and 14 Age Group. Atabesbd, 2010; 12 (2):44-57.

19. Spriet L L, Maclean D A, Dyck D J, Hultman E, Cederblad G, Graham T E. Caffeine Ingestion And Muscle Metabolism During Prolonged Exercise In Humans. Am $J$ Physiol. 1992; 262 (6Pt1):E891-8. https://doi.org/10.1152/ajpendo.1992.262.6.E891

20.Brian D, Keisler, MD, Thomas D, Armsey MD. Caffeine as an Ergogenic Aid. Current Sports Medicine Reports, 2006; 5:215-219. https://doi.org/10.1007/s11932-006-0050-z

21.Ersoy G. Nutrition for Exercise and Sports Performance. Ankara: Script Book Release Distribution; 2010.

22.Baatig K. Acute and Chronic Cardiovascular And Behavioural Effects Of Caffeine, Aspirin And Ephedrine. International Journal Of Obesity. 1993; 17 (Suppl.1): S61-64.

23.Lombardo JA. Stimulants And Athletic Performance (Part 1): Amphetamines And Caffeine. Physician Sportsmed. 1986; 14 (11):128-140. https://doi.org/10.1080/00913847.1986.11709228

24.Leonard T K, Watson R R, Mohs M E. The Effects Of Caffeine On Various body Systems: A Rewiew. J Am Diet Assoc. 1987; 87(8):1048-1053.

25.LaboniaWd, MorelliOh, GimenezMi,FreulerPv, MorelliO.H. Effects Of LCarnitine On Sodium Transport İn Erythrocytes From Dialysed Uremic Patients. Kidney Int. 1987;32:754-759. https://doi.org/10.1038/ki.1987.271

26.Eichner EW. The Caffeine Controversy: Effects On Endurance And Cholesterol. Physician Sportsmed. 1986; 14:124-132. https://doi.org/10.1080/00913847.1986.11716467

27.Powers SK, Byrd RJ, Tulley R, Callender T. Effects Of Caffeine Ingestion On Metabolism And Performance During Graded Exercise. Eur J Appl Physiol. 1983; 50:301-307. https://doi.org/10.1007/BF00423236

28.Borum PR. Carnitine. Ann Rev Nutr, 1983; 3: 233-259. https://doi.org/10.1146/annurev.nu.03.070183.001313

29.Khalil RH, Soliman MRI. Diazepam Alters Caffeineİnduced Effects On B- Endorphin Levels İn Specific Rat Brain Regions. Life Sci, 1997; 61: 2485-90. https://doi.org/10.1016/S0024-3205(97)00983-1

30.Dodd SL, Herb RA, Powers SK. Caffeine And Exercise Performance. An Update Sports Medicine. 1993; 15(1):14-23. https://doi.org/10.2165/00007256-199315010-00003

31.Birkett DJ, Miners J.O. Caffeine, Renal Clearance And Urine Caffeine Concentrations During Steady State Dosing. Implications For Monitoring Caffeine İntake During Sports Events. Br. J. Clin Pharmacol. 1: 1991: 405-408. https://doi.org/10.1111/j.1365-2125.1991.tb05553.x

32.Son HY, Nishikawa A, Kanki K, Okazaki K, Kitamura Y, Lee KY, Umemura T, Hirose M. Synergistic İnteraction Between Excess Caffeine And Deficient 
Iodine On The Promotion Of Thyroid Carcinogenesis in Rats Pretreated With N-Bis (2-Hydroxypropyl) Nitrosamine. Cancer Sci, 2003; 94( ):, 334-7. https://doi.org/10.1111/j.1349-7006.2003.tb01442.x

33.Dager SR, Layton ME, Strauss W, Richards TL, Heide A, Friedman SD, Artru AA, Hayes CE, Posse S. Human Brain Metabolic Response to Caffeine and the Effects of Tolerance. Am J.Psychiatry,1999;156:229-37. https://doi.org/10.1176/ajp.156.2.229

34.Van Soeren M H Graham T E, Rush JW E. Caffeine And Exercise: Metabolism And Performance. Can J Appl Physiol. 1994; 19 (1):111-138, 35. https://doi.org/10.1139/h94-010

35.Mohr T, Van Soeren M, Graham TE, Kjaer M. Caffeine İngestion And Metabolic Responses Of Tetraplegic Humans During Electrical Cycling. American Physiological Society Seeks Founding Editor in Chief for New High-Profile Open Access Journal. 1998;85:979-85. https://doi.org/10.1152/jappl.1998.85.3.979

36. Graham TE, Helge JW, Mac Lean DA. Caffeine Ingestion Does Not Alter Carbohydrate Or Fat Metabolism in Human Skeletal MuscleDuringExercise.JPhysiol(London), 2000;529:837-47. https://doi.org/10.1111/j.1469-7793.2000.00837.x

37.Ivy JL, Costill DL, Fink WJ. Influence Of Caffeine And Carbohydrate Feedings On Endurance Performance. Med Sci Sports, 1979; 11: 6-11.

38.Graham TE, Spriet LL. Performance and metabolic responses to a high caffeine dose during prolonged exercise. Journal of Applied Physiology, 1991;71:2292-8 https://doi.org/10.1152/jappl.1991.71.6.2292

39.Erickson MA, Schwarzkopf RJ, McKenzie RD. Effects Of Caffeine, Fructose, And Glucose İngestion On Muscle Glycogen Utilization During Exercise. Med Sci Sports Exerc,1978;19:579-83. https://doi.org/10.1249/00005768-198712000-00007

40.Jackman ML, Gibala MJ, Hultman E, Graham TE. Nutritional Status Affects Branched-Chain Oxoacid Dehydrogenase Activity During Exercise İn Humans. Am. J. Physiol. 1997; 272 (35): E233-E238. https://doi.org/10.1152/ajpendo.1997.272.2.E233

41.Chesley AE, Murphy GP. Association Of Free Psa Percent, Total Psa, Age, And Gland Volume in The Detection Of Prostate Cancer. Prostate. 1998; 39: 153-160. h t t p s:// doi org/10.1002/( S I C I ) 1097 0045(19990515)39:3<153:AID-PROS2>3.0.CO;2-V

42.Greer F, Friars D, Graham TE. Comparison of caffeine and theophylline ingestion: exercise metabolism and endurance. $J$ Appl Physiol, 2000; 89: 1837-44. https://doi.org/10.1152/jappl.2000.89.5.1837

43.Laurent D, Scheider KE, Prusaczyk WK, et al. Effects Of Caffeine On Muscle Glycogen Utilization And The Neuroendocrine Axis During Exercise. $J \quad$ Clin Endocrinol Metab, 2000;85:2170-5. https://doi.org/10.1210/jcem.85.6.6655

44.Graham TE, Helge JW, MacLean DA. Caffeine İngestion Does Not Alter Carbohydrate Or Fat Metabolism İn Human Skeletal MuscleDuringExercise.JPhysiol(London), 2000;529:837-47. https://doi.org/10.1111/j.1469-7793.2000.00837.x

45.Marsh GD, McFadden RG, Nicholson RL, Theophylline Delays Skeletal Muscle Fatigue During Progressive Exercise. Am Rev Respir Dis, 1993: 147: 876-883. https://doi.org/9. 10.1164/ajrccm/147.4.876

46. Wemple R, Lamb D, McKeever K. Caffeine vs Caffeine-Free Sports Drinks: Effects on Urine Production at Rest and During Prolonged Exercise.
International Journal of Sports Medicine, 1997;18:40-6. https://doi.org/10.1055/s-2007-972593

47.Erdoğan O, Erhan SE, Şen I. The Effect Of Different Usage Of Caffeine On The Metabolism Of Sportsmen. Erzurum: Atatürk University, Institute of Health Sciences; 2009.

48.Foskett A, Ali A, Gant N. Caffeine Enhances Cognitive Function And Skill Performance During Simulated Soccer Activity. Int $J$ of Sport Nutr Exerc Meta, 2009; 19:410-23. https://doi.org/10.1123/ijsnem.19.4.410.

49.49. Crowell D. Effect Of Caffeine İngestion On Cardiorespiratory Endurance İn Men And Women. Res QExerc Sport, 1985; 56: 301-5. https://doi.org/10.1080/02701367.1985.10605333

50.Falk B, Burnstein R, Rosenblum J. Effects Of Caffeine Ingestion On Body Fluid Balance And Thermoregulation During Exercise. Can J Physiol Pharmacol, 1990; 68: 889-92. https://doi.org/10.1139/y90-135

51.Haldi J, Bachmann G, Ensor C. The Effect Of Various Amounts Of Caffeine On The Gaseous Exchange And The Respiratory Quotient İn Man. J Nutr; 1941; 21: 307-20. https://doi.org/10.1093/jn/21.3.307

52.Gemmill CL. The effect of alloxan on muscle glycolysis. American Journal of Physiology-Legacy Content, 1947;150:613-7. https://doi.org/10.1152/ajplegacy.1947.150.4.613

53.Asmussen E, Boje O. The Effect Of Alcohol And Some Drugs On The Capacity For Work. Acta Physiol. Scand., 1948; 15(2): 109-113. https://doi.org/10.1111/j.1748-1716.1948.tb00488.x

54.Weiss, B. Laties, V.G. Enhancement Of Human Performance By Caffeine And The Amphetamines, Pharmacological Reviews March, 1962, 14 (1): 1-36.

55.Berglund B, Hemmingsson P. Effects Of Caffeine Ingestion On Exercise Performance At Low And High Altitudes İn Cross-Country Skiing. Int J Sports Med, 1982; 3: 234-6. https://doi.org/10.1055/s-2008-1026094

56. Wiles JD, Bird SR, Hopkins J. Effect Of Caffeinated Coffee On Running Speed, Respiratory Factors, Blood Lactate And Perceived Exertion During 1500-M Treadmill Running. Br J Sports Med, 1992; 26: 116-20. https://doi.org/10.1136/bjsm.26.2.116

57.Collomp K, Ahmaidi S, Chatard JC. Benefits Of Caffeine İngestion On Sprint Performance in Trained And Untrained Swimmers. Eur J Appl Physiol, 1992; 64: 377-80. https://doi.org/10.1007/BF00636227

58.Anselme F, Collomp K, Mercier B. Caffeine Increases Maximal Anaerobic Power And Blood Lactate Concentration. Eur J Appl Physiol, 1992; 65: 188-91. https://doi.org/10.1007/BF00705079

59. Weir J, Noakes TD, Myburgh K. Ahigh Carbohydrate Diet Negates Themetabolic Effects Of Caffeine During Exercise. Med Sci Sports Exerc, 1987; 19: 100-5. https://doi.org/10.1249/00005768-198704000-00006

60.Nehlig A, Debry G. Caffeine And Sports Activity: A Review. Int $J$ Sports Med, 1994; 15: 215-23. https://doi.org/10.1055/s-2007-1021049

61.Graham TE, McLean C. Gender Differences İn The Metabolic Responses To Caffeine. In: Tarnopolsky M, Editor. Gender Differences Inmetabolism: Practical And Nutritional Implications. Boca Raton: CRC Press: 1999. P. 301-27.

62.Gotzsche PC. Is There Logic In The Placebo? Lancet, 1994; $344 \quad$ (1): 925-926. https://doi.org/10.1016/S0140-6736(94)92273-X

63.Bordy H. The Lie That Heals: The Ethics Of Giving Placebos. Ann Intern Med, 1982; 97: 112-118. 
https://doi.org/10.7326/0003-4819-97-1-112

64.Forrester J. Truth Games. İstanbul: Detail Publications; 1999. 65.Dachir S, Kadar T, Robinson B. Cognitive Deficits İnduced İn Young Rats By Long-Term Corticosterone Administration. Behav Neural Biology. 1993; 60:103-109. https://doi.org/10.1016/0163-1047(93)90173-F

66.Sachdev P, Mason C and Pavlovic DH. Case Control Study Of Neuroleptic Malignant Syndrome. Am J Psychiatry, 1997; 154:1156- 1158. https://doi.org/10.1176/ajp.154.8.1156

67.Spiro H. Doctors, Patients and Placebos. New Haven: Yale University Press, 1986. https://doi.org/10.1152/physrev.00043.2012

68.Hulston CJ, Jeukendrup AE. Substrate Metabolism And Exercise Performance With CaffeineAnd Carbohydrateİntake. Medicine \& Science in Sports \& Exercise, 2008;40:2096-2104. https://doi.org/10.1249/MSS.0b013e318182a9c7

69.Lara B. et al. Caffeine-Containing Energy Drink Improves Physical Performance In Female Soccer Players. Amino Acids, 2014, 46(5): 1385- 1392. https://doi.org/10.1007/s00726-014-1709-z

70.Burke, L.M. Caffeine And Sports Performance. Appl Physiol Nutr Metab. 2008;33(6):1319-34. https://doi.org/10.1139/H08-130

71.McLellan TM, Kamimori GH, Voss DM, Bell DG, Cole KG, Johnson D. Caffeine Maintains Vigiliance And İmproves Run Times During Night Operations For Special Forces. Aviat Space Environ Med, 2005, 76:647-54.

72.Hogervorst E, Bandelow S, Schmitt J, Jentjens R, Oliveira M, Allgrove J, Carter T, Gleeson M. Caffeine İmproves Physical And Cognitive Performance During Exhaustive Exercise.
Medicine \& Science in Sports \& Exercise, 2008; 40: 1841-51. https://doi.org/10.1249/MSS.0b013e31817bb8b7

73.Babu KM, Church R, Lewander W. Energy Drinks: The New Eye-Opener For Adolescents. Clinical Pediatric Emergency Medicine,2008:9-35. https://doi.org/10.1016/j.cpem.2007.12.002

74.Astorino TA, Martin BJ, Schachtsiek L, Wong K, $\mathrm{Ng}$ K. Minimal Effect Of Acute Caffeine İngestion On İntense Resistance Training Performance. $J \quad$ Strength Cond Res. 2011;25(6):1752- 8. https://doi.org/10.1519/JSC.0b013e3181ddf6db

75. Hewlett P, Smith A. Effects of repeated doses of caffeine on performance and alertness: new data and secondary analyses. Human Psychopharmacology: Clinical and Experimental, 2007;22:339-50. https://doi.org/10.1002/hup.854

76.Haskell CF, Kennedy DO, Wesnes KA, Scholey AB. Cognitive And Mood İmprovements Of Caffeine İn Habitual Consumers And Habitual Non-Consumers Of Caffeine. Psychopharmacology, 2005; 179: 813-25. https://doi.org/ 10.1007/s00213-004-2104-3

77.Hindmarch I, Quinlan PT, Moore KL, Parkin C. The Effects Of Black Tea And Other Beverages On Aspects Of Cognition And PsychomotorPerformance. Psychopharm, 1998;139:230-240. https://doi.org/ 10.1007/s002130050709

78.Herz N. Archaeological Obsidian Studies: Method And Theory, Geoarchaeology. An International Journal, 1999;14(6): 589-594. h t t p s:// d o i.org/ $10.1002 /$ ( S I C I ) 1520 6548(199908)14:6<591:AID-GEA7>3.0.CO;2-I

\section{Information about the authors:}

Karabağ S.; http://orcid.org/0000-0002-4946-3298; sezgin_1905karadagli@hotmail.com; Faculty of Sport Sciences, Sakarya University of Applied Sciences; Esentepe Campus Serdivan Sakarya, 54050, Turkey.

Taş Z. (Corresponding author); http://orcid.org/0000-0001-7781-5898; zekitas54@gmail.com; Faculty of Sport Sciences, Sakarya University of Applied Sciences; Esentepe Campus Serdivan Sakarya, 54050, Turkey.

Cite this article as:

Karabağ S, Taş Z. The examination of the effect of caffeine supplementation in professional soccer players. Physical education of students, 2019;23(3):129-141. https://doi.org/10.15561/20755279.2019.0304

This is an Open Access article distributed under the terms of the Creative Commons Attribution License, which permits unrestricted use, distribution, and reproduction in any medium, provided the original work is properly cited http://creativecommons.org/licenses/by/4.0/deed.en

Received: 15.04.2019

Accepted: 19.05.2019; Published: 28.06.2019 